\title{
WHO International Classification of Diseases (ICD) Revision Process: incorporating rare diseases into the classification scheme: state of art
}

\author{
Ségolène Aymé*, Ana Rath, Bertrand Bellet \\ From 5th European Conference on Rare Diseases (ECRD 2010) \\ Krakow, Poland. 13-15 May 2010
}

World Health Organisation has established various Topic Advisory Groups to serve as planning and coordinating advisory bodies in the update and revision process for specific areas of the ICD. A Revision Steering Group oversees the overall revision process. Working groups organised by the Topic Advisory Groups (TAG) review the proposals. A TAG for rare diseases was established in April 2007 as rare diseases should now be traceable in mortality and morbidity information systems. The production of the basic information needed to establish an Alpha draft of the classification of rare diseases has been assigned to Orphanet and may serve as a template for the whole revision process, as rare diseases are present in all areas of medicine. Currently, the Orphanet database includes over 6,000 distinct phenotypes which are classified according to published classifications. These classification systems are mainly based on scientific grounds (aetiology and mechanism). To complement these classifications, Orphanet has developed a strictly clinical in-house classification to meet the needs of clinicians: they can be viewed on the Orphanet website. They serve to elaborate a proposal for the ICD revision. The first revised chapters currently circulating among experts and expert groups for review are Haematology, Endocrinology, Nutrition, Metabolism and Immunology. The next chapters to be considered are Neurology, Malformation and Multi-systemic diseases. Input from the Rare Disease Community is expected. It is the responsibility of TAG members to contact experts from their region of the world to ensure the widest possible consultation. The alpha draft of the chapters which have already been revised will be published in April

\footnotetext{
* Correspondence: segolene.ayme@inserm.fr

Orphanet - Inserm SC11, Inserm, Plateforme Maladies Rares, 96 rue Didot, 75014 Paris, France
}

2010 and the beta draft, for field testing, is planned for 2011.The budget of the working group on coding and classification of rare diseases is currently provided by a grant of the European Commission supporting the activities Rare Disease Task Force's Scientific Secretariat.

Published: 19 October 2010

doi:10.1186/1750-1172-5-S1-P1

Cite this article as: Aymé et al:: WHO International Classification of Diseases (ICD) Revision Process: incorporating rare diseases into the classification scheme: state of art. Orphanet Journal of Rare Diseases 2010 5(Suppl 1):P1.
Submit your next manuscript to BioMed Central and take full advantage of:

- Convenient online submission

- Thorough peer review

- No space constraints or color figure charges

- Immediate publication on acceptance

- Inclusion in PubMed, CAS, Scopus and Google Scholar

- Research which is freely available for redistribution

Submit your manuscript at www biomedcentral.com/submit
C Biomed Central 